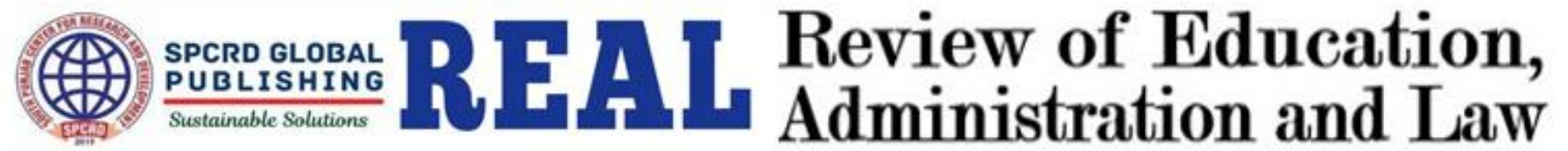 Journal homepage: http://real.spcrd.org ISSN (Print): 2708-1788 ISSN (Online): 2708-3667
}

\section{Impact of Vocational Training on Economic Empowerment of Youth in Rural Areas of Punjab}

\author{
${ }^{a}$ Aliya Khalid, ${ }^{\mathrm{b}}$ Uzma Aashiq, ${ }^{\mathrm{c}}$ Muhammad Shahid Iqbal, ${ }^{\mathrm{d}}$ Syed Salman Hassan \\ ${ }^{a}$ Assistant Professor, Department of Social Work, University of the Punjab, Pakistan. \\ ${ }^{\mathrm{b}}$ Assistant Professor, Department of Social Work, University of Sargodha, Sargodha, Pakistan. \\ ${ }^{c}$ PhD Scholar, Department of Social Work University of the Punjab, Lahore, Pakistan. \\ ${ }^{\mathrm{d}}$ Deputy Director ORIC, Virtual University of Pakistan. \\ Email: drsalman1826@gmail.com
}

\begin{tabular}{l}
\hline ARTICLE DETAILS \\
\hline History: \\
Accepted 12 Sep 2020 \\
Available Online 30 Sep 2020 \\
\\
Keywords: \\
Vocational Skills, Empowerment, \\
Pass-Out Trainees, Economic \\
Status, Income Generating \\
Activities, Punjab Vocational \\
Training Council
\end{tabular}

JEL Classification:

J24, M54, D31

DOI: $10.47067 /$ real.v3i2.76

\begin{abstract}
The current study was conducted to evaluate the role of Punjab Vocational Council in promoting empowerment of youth in rural areas of District Bhakkar. It was a case study of vocational training institutes working under Punjab Vocational Training Council (PVTC). Out of o6 vocational training institutes of District Bhakkar, o3 institutes were selected as sample, 180 pass-out trainees were selected from these institutions by using stratified random sampling method. It was a quantitative research; hence survey method was used to gather information from the respondents. Study findings clearly demonstrated that vocational training plays a vital role in improving economic status of youth and has not only increased their income, but has also increased their food, education and health expenditures as well. Study indicated that majority of respondents were involved in income generating activities and were able to add in their monthly family income. Chisquare tests confirmed that vocational training had a significant impact in enhancing economic conditions of youth in rural areas.
\end{abstract}

(C) 2020 The authors. Published by SPCRD Global Publishing. This is an open access article under the Creative Commons AttributionNonCommercial 4.0

Corresponding author's email address: drsalman1826@gmail.com

\section{Introduction}

Technical or vocational training aims to provide skilled labor in different fields but it does not contribute to improve their formal education level (UNESCO, 2009). Technical education and vocational training are considered as the key elements for ensuring development of any country. Provision of vocational education and training to youth is very much important for the economic and social development of any country (David \& Grace, 2012). Without participation of youth in the economic 
activities, no country can either make progress or can achieve the set goals and targets (David \& Grace, 2012).

Vocational training and skill development not only boost efficiency and productivity of youth but it also contributes towards a healthy competition in the worldwide economy. Worldwide, all the countries are making efforts for the promotion of vocational training and technical education to engage underprivileged youth in the economic activities which enable them to improve their economic status as well (Alhasan, Usman\&Tyabo, 2013).

In the modern world skilled labor is need of the industrial sector. Vocational training enables the pass-outs to apply their skills practically in various trades. It focuses on enhancement of skills and expertise in student. It enhances students' skills in different trades and leads towards industrial, technological and economic development of a country. Vocational training and technical education institutions produce skilled labor to fulfill the demand of industry (Mathewes \&Arulsamy, 2019).

To empower youth in rural areas, their training in different sectors is very much required. Vocational training is considered as influential mechanism against hunger, poverty, and marginalization and to empower youth. It is always expected that skilled and educated youth have higher and handsome income, good health, and worth in decision making at household and community level. Different studies from the South Asian and African countries indicated that educated youth pay more attention towards the education and health of their children and thus try to break the vicious circle of hunger and poverty. Technical education and vocational training are considered as necessary constituents of strategy of any nation to improve its industrial and agricultural products and to eliminate poverty. Awareness and knowledge about the improved manufacturing techniques, modern technologies, new markets, businesses, products, and social skills of decision making and conflict management can make a big difference in personal and nation's development (Food and Agriculture Organization, 2010).

Beside the provision of vocational training opportunities for men, the provision of such opportunities for women is also very important to empower them. It is needed to impart modern vocational skills in various trades of agriculture and industry. To improve the living standard of rural women, provision of technical skills of growing and preserving food; loans to start their own entrepreneurship; and access to markets without intervention of middle man for selling their products is much needed (Britto, 2012).

Vocational training is very essential to increase efficiency, production, employment opportunities and to enhance and ensure economic growth, income generating activities, sustainable rural development and food security. Although rural women play an important role in agriculture sector and participate in many agricultural activities, yet they are not allowed to get education and participate in vocational training programs to enhance their skills and knowledge to perform different managerial and leaderships roles for the development of their community (Gender and rural employment policy brief 2, 2010).

In the development process men and women are equally important. Actually women employability, social and economic status of women are indicators of a development of any nation. Without women participation in social, economic and political activities, development of nation will be ceased. Economically empowered women play a significant role for the well being of their family, 
community and country. To empower women, they should have enhanced control over economic resources and access to educational and training opportunities (Blumberg et al. 1995).

The specific objectives of this research were to study the participation trend of youth in vocational training programs; the impact of vocational skills on economic status of youth and their families in rural areas and the problems faced by rural youth while performing income generating activities.

\section{Review of the Literature}

Lama (2012) stated in his study that vocational training is very much important in this modern age. The speedy changes in the economic systems and formations of global markets, inventions, and technological development have increased the demand of professionalism and vocational training to improve individual ability, efficiency and for overall development of a country. Vocational training programs are equally important for the educated and illiterate people to enhance their skills to improve their economic status, their labor efficacy, self-employability and their control over financial resources. Job opportunities and placement of trainees in different industrial, service, agricultural and manufacturing sectors has increased the importance of Vocational training and technical education.

UNESCO (2009) in a research study described that in developing countries like India and Pakistan where a huge number of youth have no access to formal education, it is very essential to integrate vocational training programs, literacy programs and non-formal educational institutes in the national education system. Modernizing, transforming and revitalizing vocational training and technical education is required for capacity building and inclusion of rural youth and marginalized class in the mainstream and for the development of Pakistan.

Tripathi (2003) defined skill development as a process of capacity building of individuals to perform certain functions to better their living standard. Skill development and technical training have a significant role in personal, societal, organizational, institutional and national development. Human resource development can also be ensured by imparting vocational skills to youth.

Nazir et al. (2012) concluded in the study that skill development training courses play a vital role in empowering the youth in rural areas. Vocational training enabled youth in rural areas to enhance their economic and social status and they also achieved high confidence level while making decisions regarding their own life. After getting vocational training and acting upon the suggested techniques majority of pass out trainees achieved the status of economic independence. Most importantly, it was observed that young rural women became psychologically, socially and economically empowered. After utilizing vocational skills provided by krishi Vigyan Kenderas (KVKs) women were able to generate income and make independent decisions. Training in different trades such as tailoring, cutting, food preservation, and knitting has improved their economic status.

Jutting and Morrisson (2009) in their research study described that vocational training is a key factor for those young rural women who are performing their duties as family workers, home based entrepreneurs, agricultural workers and seasonal workers. Training needs for women are different from that of men because of their domestic responsibilities and gender based nature of work in forestry, fishing, honey bee keeping and livestock management.

Sita \& Adhikari (2004) in their research observed that through participating in different incomegenerating activities women were able to improve their economic, social and political status as well as 
their influence at household and community level was also increased. It also increased their control over their personal income and they were also able to have right to own property and spend their income according to their own free will. It was all because of their increase in income.

Major portion of population in Pakistan consists of youth (15-25 years of age), that's why vocational and skill development sector must play its role to impart market oriented skills to this work force for their capacity building and to fulfill the demand of market for professional and skilled labor (Ansari \& Wu, 2013).

Pakistan is the second most populous country of South Asia region. There is a need to develop skill training programs to meet market demands especially in the sectors e.g. services, manufacturing, agriculture and industry. Vocational training is a key element for the economic growth of Pakistan. It is needed that such training programs must be introduced which enable youth to make innovations and contribute in the body of knowledge in different sectors. So it is of much importance to realize the opportunities of job for youth and taking steps to build skills in required trades to meet future demands (Naqvi et al., 2019).

Agrawal (2013) indicated that although economic development of most of the countries in Asia is due to provision of vocational training opportunities to its youth, yet in most of countries of South Asia, vocational training has not achieved the required success. Despite the efforts made by the governments of these developing countries of South Asian region, results are still not satisfactory. Vocational training programs in these countries are facing many challenges such as lack of vocational training institutes and industrial sector, lack of financial to start business, and other social challenges. Governments of these countries should address these challenges urgently to make best use of vocational training programs.

\section{Research Methodology}

The current study was conducted in Bhakkar District to observe the impact of vocational training on the economic conditions of youth in rural areas. The universe of the present research study was all the vocational training institutes of District Bhakkar, working under Punjab Vocational Training Council. There are o6 vocational training institutes of Punjab Vocational Training Council in Bhakkar. Targeted population of this study was the pass-out trainees of these six VTIs who were utilizing their skills and were involved in any sort of income generating activity. Pass out trainees from the year 2013 to 2018 were included in the current study. Multi-stage sampling method was adopted. At first stage researcher selected 03 VTIs of the district through simple random sampling technique, and at second stage through stratified random sampling technique, a sample of 180 respondents was drawn from total 4521 pass out trainees who were engaged in any sort of economic activity. Stratified random sampling method was adopted as targeted population was heterogeneous (both male and female pass out trainees).

The researcher used survey method and a structured interview schedule was used for data collection. Keeping in view the scope of the current study and sample size, the survey method was considered best to collect the data from the respondents. Software SPSS was used to analyze the data. Both inferential and descriptive statistics were used to analyze the data and draw the conclusion. Chisquare test was used to check the relationship between the variables.

\section{Findings \& Results}

Table 1 shows the distribution of respondents regarding participation of respondents in different 
trades of vocational training. According to the data majority of the respondents were interested in information technology as 33\% (59) respondents had got diploma in Computer Application \& Office Professional. Data also indicated that many of respondents were also much interested in the trade of Beautician because of its high demand, it was noted that 25\% (45) respondents had got diploma in beautician, 12\% (22) respondents in Dress Making, 14\% (26) respondents were Electrician, $7 \%$ (12) respondents were Auto Mechanic, while 7\% (13) respondents received training in agriculture and livestock and $2 \%$ (3) respondents received training in plumbing.

Table 1: Percentage Distribution of Respondents regarding Participation in different Trades

\begin{tabular}{|l|c|c|}
\hline \multicolumn{1}{|c|}{ Trades } & Frequency & Percent Value \\
\hline Beautician & 45 & 25 \\
\hline Agriculture and Live Stock & 13 & 7 \\
\hline Dress Making & $\mathbf{2 2}$ & 7 \\
\hline Auto Mechanic & 12 & 14 \\
\hline Electrician & 26 & 2 \\
\hline Plumber & 3 & 33 \\
\hline $\begin{array}{l}\text { Computer Application \& Office } \\
\text { Professional Total }\end{array}$ & 59 & $\mathbf{1 0 0}$ \\
\hline \multicolumn{2}{|c|}{} \\
\hline
\end{tabular}

Table 2 indicates that Majority of the respondents i.e. 31\% (55) were involved in income generating activities for 4 or more than 4 years, $27 \%$ (49) respondents were performing income generating activities since 3 years. 25\% (46) respondents were involved in economic activities for 2 years, while only $17 \%$ (30) respondents were engaged in income generating activities since 1 years or less than 1 year.

Table 2: Period of Involvement in Income Generating Activities

\begin{tabular}{|l|c|c|}
\hline \multicolumn{1}{|c|}{ Years } & Frequency & Percent Value \\
\hline 1 or less than 1 Year & 30 & 17 \\
\hline 2 Years & 46 & 25 \\
\hline 3 Years & 49 & 31 \\
\hline 4 Years \& above & 55 & $\mathbf{1 0 0}$ \\
\hline Total & $\mathbf{1 8 0}$ & \\
\hline
\end{tabular}

Table 3 demonstrates that out of 180 respondents, $47 \%$ (84) respondents were self-employed, 27\% (48) respondents were doing private job. 17\% (31) respondents were involved in the business of their family members or extending the business set by their family, while only 9\% (17) respondents were in government jobs. 
Table 3: Different Sort of Income Generating Activities being performed by Youth

\begin{tabular}{|l|c|c|}
\hline \multicolumn{1}{|c|}{ Nature of work } & Frequency & Percent Value \\
\hline Government Job & 18 & 10 \\
\hline Private Job & 45 & 25 \\
\hline Extension in Old Business & 31 & 17 \\
\hline Self-Employment & 86 & 48 \\
\hline \multicolumn{1}{|c|}{ Total } & $\mathbf{1 8 0}$ & $\mathbf{1 0 0}$ \\
\hline
\end{tabular}

Table 4 carries the data about respondents' monthly income.. According to data out of $180,35 \%$ (63) respondents were earning Rs.5001-1000o/- per month, while monthly income of 29\% (52) respondents was Rs. 15001-20000. Respondents earning Rs. 10001-15000 were 21\% (38) and respondents earning Rs. 20001\& above were $15 \%$ (27).

Table 4: Monthly Income of Respondents

\begin{tabular}{|c|c|c|}
\hline Amount in Rupees & Frequency & Percent Value \\
\hline $5001-10000$ & 63 & 35 \\
\hline $10001-15000$ & 38 & 21 \\
\hline $15001-20000$ & 52 & 29 \\
\hline $20001 \&$ above & 27 & 15 \\
\hline Total & $\mathbf{1 8 0}$ & $\mathbf{1 0 0}$ \\
\hline
\end{tabular}

Table 5 describes that $79 \%$ respondents reported improvement in their economic status as they were involved in the income generating activities, while $21 \%$ respondents were of the view that there is no improvement in their economic status as not they were earning very less.

Table 5: Economic Status of Respondents

\begin{tabular}{|c|c|c|}
\hline Improvement in Economic Status & Frequency & Percent Value \\
\hline Yes & 142 & 79 \\
\hline No & 38 & 21 \\
\hline Total & $\mathbf{1 8 0}$ & $\mathbf{1 0 0}$ \\
\hline
\end{tabular}

Table 6 reveals that $89 \%$ (161) respondents reported increase in their food expenditure after their involvement in income generating activities while only $11 \%$ (19) respondents said that there is no impact or increase in their expenditure on food items due to different factors.

Table 6: Improvement in Food Expenditure

\begin{tabular}{|c|c|c|}
\hline Improvement & Frequency & Percent Value \\
\hline Yes & 161 & 89 \\
\hline No & 19 & 11 \\
\hline Total & $\mathbf{1 8 0}$ & $\mathbf{1 0 0}$ \\
\hline
\end{tabular}

Table 7 shows the results about increase in educational expenditure of respondents. $74 \%$ (134) 
respondents said that now they are spending more on the education of their siblings or children.

Table 7: Improvement in Education Expenditure

\begin{tabular}{|c|c|c|}
\hline Improvement & Frequency & Percent Value \\
\hline Yes & 134 & 74 \\
\hline No & 46 & 26 \\
\hline Total & $\mathbf{1 8 0}$ & $\mathbf{1 0 0}$ \\
\hline
\end{tabular}

Table 8 carries the results about increase in health expenditure. 82\% (148) respondents claimed that now they are in a position to spend more on their own health or their family member's health.

Table 8: Improvement in Expenditure on Health

\begin{tabular}{|c|c|c|}
\hline Improvement & Frequency & Percent Value \\
\hline Yes & 148 & 82 \\
\hline No & 32 & 18 \\
\hline Total & $\mathbf{1 8 0}$ & $\mathbf{1 0 0}$ \\
\hline
\end{tabular}

Table 9 describes the problems being faced by Rural Youth during the utilization of vocational skills. According to data, $72 \%$ (129) respondents said that they were facing some problems during the utilization of their vocational skills and during their work.

Table9: Problems Faced by Rural Youth during the Utilization of Vocational Skills

\begin{tabular}{|c|c|c|}
\hline Responses & Frequency & Percent Value \\
\hline Yes & 129 & 72 \\
\hline No & 51 & 28 \\
\hline Total & $\mathbf{1 8 0}$ & $\mathbf{1 0 0}$ \\
\hline
\end{tabular}

Table 10 reveals multiple responses of 180 respondents regarding kind of problems they were facing during the utilization of their vocational skills. Lack of financial resources, lack of markets links, social hurdles, low pay packages and transportation problems were among major problems being faced by the respondents during the course of their involvement in income generating activities. 
Table 10: Types of Problems Being Faced by Respondents during the Utilization of Vocational Skills

\begin{tabular}{|c|c|c|c|c|c|c|}
\hline \multirow{2}{*}{ Nature of problems } & \multicolumn{2}{|c|}{ Yes } & \multicolumn{3}{c|}{ No } & \multicolumn{3}{c|}{ Total } \\
\cline { 2 - 7 } & Frequency & $\%$ & Frequency & $\%$ & Frequency & $\%$ \\
\hline Transportation Problem & 83 & 46 & 97 & 54 & 180 & 100 \\
\hline Low Pay Package & 67 & 37 & 113 & 63 & 180 & 100 \\
\hline Social Hurdles & 74 & 41 & 106 & 59 & 180 & 100 \\
\hline Lack of Financial resources & 129 & 72 & 51 & 28 & 180 & 100 \\
\hline Lack of Market Links & 112 & 62 & 68 & 38 & 180 & 100 \\
\hline Unfavorable working environment & 86 & 48 & 94 & 52 & 180 & 100 \\
\hline Heavy Work load & 47 & 26 & 133 & 74 & 180 & 100 \\
\hline
\end{tabular}

\subsection{Hypothesis}

$\mathbf{H}_{\mathbf{o}}=$ There is no association between vocational training and improvements in economic status of rural youth

$\mathbf{H}_{\mathbf{1}}=\quad$ There is an association between vocational training and improvement in economic status of rural youth

Level of Significance Alpha: $(\alpha)=.05$

\subsection{Chi-Square Test}

Chi squared test was applied to check the association between vocational training and improvement in economic status of Rural Youth.

Null hypothesis $\left(\mathrm{H}_{0}\right)$ was assumed: There is no association between vocational training and improvement in economic status of Rural Youth, while alternative hypothesis $\left(\mathrm{H}_{1}\right)$ was assumed: There is an association between vocational training and improvement in economic status of Rural Youth. Chisquared test was applied to test the relationship between the two variables.

Table 11 shows that there is a significant relationship between two variables as chi-square is 40.25 and $\mathrm{p}=0.000$ which is < .05. As the level of significance for the calculated value is less than .05, so null hypothesis $\left(\mathrm{H}_{0}\right)$ i.e. there is no association between vocational training and improvement in economic status of Rural Youth is rejected; it means that association between vocational training and improvement in economic status of Rural Youth exists.

Table 11: Relationship between Vocational Training and Improvement in Economic Status of Rural Youth

\begin{tabular}{|l|c|c|c|}
\hline & Value & Df & Asymp. Sig. (2-sided) \\
\hline Pearson Chi-Square & 40.250 & 9 & 0.000 \\
\hline Likelihood Ratio & 37.191 & 9 & 0.000 \\
\hline $\begin{array}{l}\text { Linear-by-Linear } \\
\text { Association }\end{array}$ & 29.530 & 1 & 0.000 \\
\hline No. of Valid Cases & $\mathbf{1 8 0}$ & & \\
\hline
\end{tabular}




\section{Discussion}

Current study indicated that majority of the respondents has got training in the field of computer as it is demand of the modern era. Another important finding was that the majority of respondents were self-employed and their average earning was up to Rs. 15000 per month. These findings indicated that due to increase in their income, economic status of the majority of youth has raised and now they are in a position to spend more on the food, health and education of themselves and their family members. These findings of the present study are similar with the findings of the research conducted by Nazir et al. (2012) and Sita \& Adhikari (2004), but on the other hand results of study conducted by Agrawal (2013) has contradicted with it and indicated that in South Asian region vocational training has not improved the economic status of the youth yet.

While talking about the problems, majority of the respondents told that due to shortage of financial resources and market linkages and inadequate coordination between industrialists and vocational training providing authorities, they are earning less despite of their efforts. They were sure if these hurdles are removed they can improve their income and play their role for the development of the country as well. Findings of studies conducted by Ansari \& Wu, (2013) and Agrawal (2013) also supported this finding of the current study.

\section{Conclusion}

Pakistan's future is linked with vocational education and the country can be put on the road to progress and prosperity only by equipping the youth with modern vocational knowledge. Vocational training is an important mechanism to integrate rural youth in society and to make them a dynamic member of the society. Study concluded that technical education and skill development training programs played a fundamental role in enhancing economic conditions of youth and had made them empowered. Study indicated that a majority of pass out trainees were involved in income generating activities after getting training. Study also indicated that monthly income of respondents had been increased after getting and utilizing vocational skills. The inferential analysis also verified that vocational training had remarkable impact in improving economic conditions of youth. Study concluded that vocational training has a significant role in empowering youth in rural areas of Pakistan. Country's development can also be ensured by providing vocational training opportunities and enhancing skills in youth to participate in economic activities.

\section{References}

Agrawal, T. (2013). Vocational education and training programs (VET): An Asian perspective. AsiaPacific Journal of Cooperative Education, 14(1), 15-26.

Alhasan, N. U., \& Tyabo, A. (2013). Revitalizing technical and vocational education (TVET) for youth empowerment and sustainable development. Journal of Educational and Social Research, 3(4), 149.

Ansari, B., \& Wu, X. (2013). Development of Pakistan's technical and vocational education and training (TVET): An analysis of skilling Pakistan reforms. Journal of Technical Education and Training, 5(2).

Arulsamy, Dr.S \& Mathews,A.S. (2019). Empowering Youth with Vocational Skill through Training.infokara research journal. Coimbatore, Tamil Nadu. Bharathiar University.

Blumberg, R. L., Cathy, A. R., Irene, T. \& Michael, M. (Eds). (1995). Engendering Wealth and Well-being: Empowerment for Global Change. Boulder: West- view.

Britto, R. (2012). Empower rural women to tame poverty. Retrieved from http://www.microfinancenigeria.com/around-africa/tanzaniaempower-rural- women-to-tamepoverty 
David, E., \& Grace, O. (2012). Vocational Education of Women: A Tool for Community and National Development in Nigeria. Universal Journal of Management and Social Sciences, 2 (2), 1-5.

Gender and rural employment policy brief 2. (2010). Investing in skills for socio- economic empowerment of rural women. Rome: Food and Agriculture Organization of the United Nations. Retrieved from http://www.fao.org/docrep/o13/i20o8e/i20o8eo2.pdf

Jutting, J. and Morrisson, C. (2009). Women, bad jobs, rural area: what can Social Institutions and Gender Index (SIGI) tell us? Paper presented at the workshop on Gaps, trends and current research in gender dimensions of agricultural and rural employment: differentiated pathways out of poverty, 31 March- 2 April 2009

Lama, sukamya. (2012). Vocational Education and Training: the role of ODL. International Journal of Scientific and Research Publications.

(2)3. ISSN: $2250 \quad 3153$

Naqvi, S. A. H., Ahmad, M., \&Siddiqui, G. R. (2019). Role of National Vocational and Technical Training Commission (NAVTTC) in the Implementation of National Skills Strategies (NSS) 2009-2013. Pakistan Journal Of Distance And Online Learning, 5(2), 235-246.

Nazir, T., Vaida, N. and Dar, M.A. (2012). Impact of Krishi Vigyan Kenderas in Empowerment of Rural Women. Researcher. 4(12), 30-33. ISSN: 1553-9865 Retrieved from http://www.sciencepub.net/researcher.6

Sita, R.A. \& Adhikari, K.P. (2004). Do Income Generating Programs work to Empower Women? A discussion on the Changing Status of Women in Rural Nepal. (Ph.D Thesis). UK: The University of Reading.

Tripathi, B.D. (2003, May). Current Strategies and Future Approaches for HRD in Agricultural Extension. New Delhi, India: Paper presented in the Regional Workshop on Operationalising Reforms in Agricultural Extension in South Asia.

UNESCO. (2009, June). Research Study on Technical and Vocational Education in Pakistan at Secondary Level. Islamabad: National Institute of Science and Technical Education, Ministry of Education, Government of Pakistan. 